\title{
Legal regulation of night work and overtime work: comparative analysis
}

\section{Dilfuza ABDULLAEVA ${ }^{1}$}

Specialized Branch of Tashkent State University of Law

\section{ARTICLE INFO \\ Article history: \\ Received September 2020 \\ Received in revised form 15 \\ September 2020 \\ Accepted 25 September \\ 2020 \\ Available online \\ 1 October 2020}

\section{Keywords:}

Labor law

Labor relations

Labor legislation

Overtime

Night work time

Working week

Working hours

Features of labor relations

\begin{abstract}
The article analyzes the legal regulation of overtime and night work time in Uzbekistan and foreign countries in terms of establishing certain restrictions and payment in an increased amount compared to work in normal conditions, as well as providing additional rest time, since, according to legislators, economists, sociologists and doctors, such types of work negatively affect the health of the worker or lead to an imbalance in his family or social life.

The scientific publication analyzes the problems of establishing overtime and night work time. Based on the analysis of the current legislation in the sphere of labor, the author formulates the criteria that allow distinguishing between these types of working time.

2181-1415/@ 2020 in Science LLC.

This is an open access article under the Attribution 4.0 International (CC BY 4.0) license (https://creativecommons.org/licenses/by/4.0/deed.ru)
\end{abstract}

\section{Тунги иш вақти ва иш вақтидан ташқари ишни хуқуқий тартибга солиш: қиёсий тахлил}

\section{Калит сузллар:}

Мехнат қонунчилиги

Мехнат муносабатлари

Мехнат қонунчилиги

Иш вақтидан ташқари иш

Тунги иш вақти

Иш хафтаси

Иш вақти

Мехнат

муносабатларининг ўзига хослиги.

\begin{abstract}
АННОТАЦИЯ
Мақолада Ўзбекистонда ва хорижий давлатларда иш вақтидан ташқари иш ва тунги иш вақтларда ишлашнинг қонуний тартибга солиниши, муайян чекловларни белгилаш ва нормал шароитда ишлаш билан таққослаганда кўп миқдорда пул тўлаш, шунингдек, қўшимча дам олиш вақтини таъминлаш нуқтаи назаридан тахлил қилинган. Олимларнинг фикрига кўра, иқтисодчилар, социологлар ва шифокорлар каби ходимларнинг соғлиғига ушбу иш тури салбий таъсир
\end{abstract}

\footnotetext{
${ }^{1}$ Head of the Department of Private Law, Specialized Branch of Tashkent State University of Law, Tashkent, Uzbekistan email: dilfuza.abdullayeva@yandex.ru
} 
қилиши, унинг оиласида ёки ижтимоий хаётида салбий мувозанатни келтириб чиқариши назарда тутилган.

Илмий мақолада иш вақтидан ташқари иш ва тунги иш вақтини белгилаш муаммоларини тахлил қилинган. Мехнат сохасидаги амалдаги қонунчиликни тахлил қилиш асосида иш вақтини ажратишга имкон берадиган мезонларни ишлаб чиқди

\section{Правовое регулирование ночной и сверхурочной работы: сравнительный анализ \\ АННОТАЦИЯ}

\section{Ключевые слова:}

Трудовое право

Трудовые отношения

Трудовое

законодательство

Сверхурочная работа

Ночное время

Рабочая неделя

время работы

Особенности трудовых

отношений
В статье анализируется правовое регулирование сверхурочной и ночной работы в Узбекистане и зарубежных странах в части установления определенных ограничений и оплаты в увеличенном размере по сравнению с работой в нормальных условиях, а также предоставления дополнительного времени отдыха. По мнению ученых, для экономистов, социологов и врачей такие виды работы негативно сказываются на здоровье рабочего или приводят к дисбалансу в его семейной или общественной жизни.

В научное статье анализируются проблемы установления сверхурочной и ночной работы. На основе анализа действующего законодательства в сфере труда автором сформулированы критерии, позволяющие различать эти виды рабочего времени.

In labor law, special attention is paid to the regulation of overtime and night work, which are considered in the aspect of establishing certain restrictions and higher wages compared to work in normal conditions, as well as providing additional rest time, since, according to legislators, economists, sociologists and physicians, such types of work negatively affect the health of the worker or lead to an imbalance in his family or social life.

Working at night disrupts the natural rhythm of life and, as proven by science, negatively affects human health. For this reason, work at night requires special regulation.

According to the first part of Art.22 Labor Code night time is from 22.00 to 6.00 in the morning. One of the peculiarities of working at night is that the duration of the work shift at night must be reduced by at least one hour in comparison with the duration of working hours established for a particular category of workers. Only in those cases when it is necessary for the conditions of production, the duration of night work is equalized with the day.

Another feature of the use of working hours at night is the restriction of night work for certain categories of workers.

From the content of Art.122 of the Labor Code shows that, as a general rule, the duration of the night shift should be reduced by one hour, with a corresponding decrease in the duration of working hours per week. Meanwhile, in some cases, legislation allows the duration of the night shift to be equalized with the day shift. In these cases, the weekly norm 
or the norm of working time for the accounting period, despite night work, is calculated in the usual manner without a corresponding decrease.

In the second part of Art.122 of the Labor Code shows only two special cases, in the presence of which the duration of night work can be equalized with day work, namely: in continuous production and shift work with a six-day work week with one day off.

As M.Yu.Gasanov, this article provides that the duration of night work is equal to the daytime, when it is necessary under the terms of production. If, in the event of a dispute, the employer cannot provide convincing evidence that the night shift is equalized with the day shift precisely for this reason, then such equalization will be considered unlawful, and hours worked overnight will be considered overtime [1].

The duration of night work can be equal to that of the day, for example, when an employee is hired to perform work at night (night watchman, plumber, electrician or other specialists hired on duty at the enterprise at night, etc.). In this case, the duration of the night shift cannot be reduced, since the above and similar jobs were created specifically for the implementation of the auxiliary functions of the enterprise precisely for the period of night time.

It is also necessary to comply with the requirement provided for in Art.220 of the Labor Code, according to which, the involvement of persons with disabilities to work at night is allowed only with their consent and provided that such work is not prohibited by medical recommendations. The same rules are established in Art.228 of the Labor Code, according to which pregnant women and women with children under the age of fourteen (children with disabilities - up to sixteen), can be involved in work at night only with their consent. Moreover, even with such consent, pregnant women and women with children under the age of three years can only be allowed to night work if there is a medical certificate confirming that such work does not threaten the health of the mother and child [2]. According to Art.245 of the Labor Code, it is prohibited to involve persons under eighteen years of age in night work.

Workers, according to the medical opinion, who are contraindicated for health reasons, should also be exempted from night work.

Specific amounts of remuneration for work at night are determined in a collective agreement, and if it is not concluded, by the employer in agreement with the trade union committee or other representative body of workers. However, for each hour of work at night, the payment must be provided for at least one and a half amount [3].

Unfortunately, in Art.122 of the Labor Code is not specified for whom exactly, the duration of work (shift) at night is not reduced, which in practice may cause a certain misunderstanding or misunderstanding between the employee and the employer.

Particular attention is drawn to the problem of regulating night work according to the legislation of foreign countries. In most countries, night work is also voluntary as a general rule, and is mandatory only in cases provided for by law. In a number of countries, it has been established that night work is compulsory if it is stipulated in a collective agreement or in an individual employment contract.

From foreign experience, one can see that the main way to stimulate work at night is increased pay. The premium is in different countries and industries from 10 to $30 \%$. Legislation and collective agreements establish additional leave for work at night, a reduced 
duration of the night shift, and exemption from such work for older workers (usually over 55) [4].

In the Russian Federation, work at night is generally regulated by the Labor Code of the Russian Federation, which states that night time is from 22:00 to 6:00. In addition, the article provides that the duration of work (shift) at night is reduced by one hour without subsequent working off. The duration of work (shift) at night is not reduced for employees who have a reduced duration of working hours, as well as for employees hired specifically for work at night, unless otherwise provided by the collective agreement [5].

The Labor Code restricts the recruitment of certain categories of workers to work at night. An absolute prohibition on being recruited to work at night is imposed on pregnant women and workers under the age of 18.

The legislator has established a certain protection against being recruited to work at night in relation to: women with children under the age of three; disabled people; workers with disabled children;

workers caring for sick family members; mothers and fathers raising children under the age of five without a spouse, as well as guardians of children of this age. These persons may be recruited to work at night:

- if they have expressed written consent to be hired to work at night;

- if the assigned work is not prohibited by him for health reasons in accordance with the medical report.

In addition, these workers must be informed in writing of their right to refuse to work at night.

Payment for work at night in accordance with Art.154 of the Labor Code of the Russian Federation is made in an increased amount for each hour of night work (from $10 \mathrm{pm}$ to $6 \mathrm{am}$ ). The specific amount of the increase in wages for work at night is established by a collective agreement, a local regulatory act or an employment contract. They cannot be lower than the minimum size stipulated by labor legislation. In accordance with the decree of the Government of the Russian Federation of July 22, 2008 No.554, such a minimum amount is $20 \%$ of the hourly wage rate (official salary) for each hour of work at night [6].

Other amounts of increased pay for night work are established by special legal acts. For example, according to the Regulation "On remuneration of medical and pharmaceutical workers of medical institutions of the Federal Service for Drug Control of the Russian Federation", an additional payment for night work is established in the amount of $50 \%$ of the hourly tariff rate (official salary) for each hour of night work. Employees of medical institutions and medical units involved in the provision of emergency, ambulance and emergency medical care, field personnel and communication workers of emergency medical departments are paid an additional payment for work at night in the amount of $100 \%$ of the hourly wage rate (official salary).

In France, night work is subject to detailed regulation by the French legislator. Work from 21 to 6 am considered work at night. As an exception for workers in the field of television and radio broadcasting, the press, nightclubs, night time is considered to be the period from 24 to 7 in the morning [7].

However, work at night is considered an exception to the general rule on labor protection. In this case, the employer must take into account the additional health and safety requirements at the workplace. The use of workers at night must be justified by the need to 
maintain the continuity of economic activity or other social necessity. Moreover, if the performance of work at night becomes incompatible with the employee's family obligations, such as raising a child, or guardianship of an incapacitated person, the employee may refuse such work, and this refusal will not be considered a basis for terminating the employment relationship [8].

The recruitment of employees to work at night should be pre-established in a collective bargaining agreement or industry agreement. In the absence of such a contract or agreement, the employee may be hired to work at night, provided that preliminary negotiations have been held with him and the permission of the inspector is obtained labor.

According to the legislation, the total duration of work at night work cannot exceed - 8 hours during the day, and 40 hours during the week.

All employees working at night are entitled to an additional medical examination every 6 months.

Compensation for night work is increased and is doubled.

In the United States, there is no general legal regulation for night work that would cover all categories of workers. The specifics of regulating work at night are established separately for each category of workers. Civil servants can be cited as an example. Night work is defined as work performed between 18:00 and 06:00 in accordance with Title 5 № 5545 of the United States Code.

For the performance of night work, employees are paid a salary and additional compensation in the amount of up to $10 \%$ of the salary. Restrictions on recruiting workers to work at night are contained in various titles of the US Code of Laws, the Code of Federal Regulations and other bylaws that govern the work of certain categories of workers, such as minors and women [9].

A comparative analysis of the legal regulation of night work in a number of foreign countries has led to a number of conclusions.

Night time in these countries is defined in different ways: in the Russian Federation 22.00 to 6.00; in France - from 21.00 to 6.00 in the morning; in the USA - from 18.00 to 6.00; and the Republic of Uzbekistan - from 22.00 to 6.00 in the morning.

At the same time, attention is drawn to the fact that in France, at the legislative level, compensation is provided for at least double the amount for work at night and free medical examination, which, in our opinion, is one of the social protection of such workers.

Based on the above, the experience of France should be taken into account, and provided in Art.122 of the Labor Code of the Republic of Uzbekistan, mandatory medical examination of workers involved in night work once every six months.

This is justified by the fact that night work is associated with increased traumatism, and thus such work leads to a violation of the biological rhythms of a person. The human body is tuned to stay awake during the day and rest at night. As a result, there is a biorhythm failure, which can lead to serious illness.

According to the first part of Art.124 of the Labor Code, overtime work is considered to be work in excess of the duration of daily work established for the employee [10].

As noted in paragraph 2.1 of this work, the specific duration of daily work is determined by the internal labor regulations or shift (work) schedules. Daily work in excess of this duration should be considered overtime. 
Suppose one worker has a five-day working week with two days off and has a normal daily work duration of 8 hours. Another, working in unfavorable working conditions in the same mode, is given a reduced (7 hours) duration of daily work. Consequently, for each of these workers, work in excess of the duration established for them (respectively, over eight, seven hours) will be considered overtime.

According to the second part of Art. 124 of LC overtime work may be applied only with the consent of the employee. Consequently, a collective agreement, collective agreement, as well as an employment agreement cannot provide for any exceptional cases or circumstances, upon the occurrence of which the employer has the right to involve employees in overtime work without their consent. Personal consent of the employee must be obtained on a case-by-case basis when engaging him in overtime work.

It is prohibited to engage in overtime work, even with consent:

- persons under the age of eighteen (Article 245 of the Labor Code);

- disabled people of I and II groups, if such work is prohibited for them by medical recommendations (part five of article 220 of the Labor Code);

- employees, the duration of the work shift is set at twelve hours (part three of article 124 of the Labor Code);

- workers performing work with especially difficult and especially harmful working conditions (part three of article 124 of the Labor Code).

As a general rule, according to Art.125 Labor Code, the duration of overtime work cannot exceed four hours for each employee for two consecutive days. That is, if on the first day the employee worked four hours overtime, then the next day, even with his consent, it is no longer acceptable to involve him in such work. Accordingly, if the duration of overtime work on the first day was three hours, then the next day, this employee may be allowed to work overtime, but not more than one hour.

In addition, Art.125 of the Labor Code provides that when performing work with harmful and difficult working conditions, the maximum rate of overtime work is no more than two hours a day. The maximum annual rate of overtime work during the year in all cases may not exceed one hundred and twenty hours [11].

Part two of Art.125 of the Labor Code obliges the employer to timely keep accurate records of the working hours actually worked by each employee, including overtime work.

According to the first part of Art.157 of the Labor Code, overtime work should be paid at least in double the amount or not less than in a single amount, if it is compensated by the provision of time off at the request of the employee. At the same time, it is important to pay attention to the fact that the Code determines only the obligatory minimum amount of its payment. That is, at the enterprise, on a local basis, remuneration for overtime work can be established at more than double the amount [12].

It should be emphasized that compensation for overtime work by providing time off is possible only if the employee himself wishes.

In most countries, overtime is also generally voluntary and is only mandatory in cases provided for by law. Several countries have established that overtime is compulsory, if it is stipulated in the collective agreement or in the individual labor agreement.

There is a group of countries where the duration of overtime is not legally limited for all employees (federal legislation of the USA, Denmark) or is not limited only for adult male workers (UK, Japan). 
In the UK, if the employment contract does not stipulate an obligation for the employee to work overtime at the employer's request, the employee may refuse to comply with this requirement. But if such obligation is written down in the employee's employment contract, then the refusal to work overtime will be regarded as a gross violation of labor discipline. In most countries, the employer must justify the need for overtime work, with the exception of the UK and France [13].

According to the legislation of the Russian Federation, overtime work is considered to be work performed in excess of the duration of daily work established by the shift schedule, and in the case of summarized accounting of working hours, work performed in excess of the normal number of working hours for the accounting period. Depending on the circumstances that have caused the need for overtime work, it is envisaged to involve employees in overtime work both with their written consent and without obtaining such consent. Without the consent of the employee, the employer has the right to involve him in overtime work only in the presence of extraordinary circumstances, namely:

- during the performance of work necessary to prevent a disaster, industrial accident or natural disaster;

- when performing socially necessary work to eliminate circumstances that disrupt the normal functioning of centralized hot water supply, cold water supply or sewerage systems, gas supply systems, heat supply, lighting, transport, communications;

- when performing work, the need for which is due to the introduction of a state of emergency or martial law, as well as urgent work in emergency conditions, i.e. in the event of a disaster or threat of disaster (fires, floods, famine, earthquakes, epidemics or epizootics) and in other cases endangering the life or normal living conditions of the entire population or its part [14].

With written consent, it is allowed to involve employees in overtime work in the following cases provided by law:

- if necessary, to complete the work begun, which, due to the delay, could not be completed within the duration of the working time established for the employee, if the failure to complete this work may lead to damage or loss of the employer's property, or pose a threat to the life and health of people;

- in the production of temporary work on the repair and restoration of mechanisms or structures in cases where their malfunction may cause the termination of work for a significant number of workers;

- to continue work in the absence of a shift worker, if the work does not allow a break. In these cases, the employer is obliged to immediately take measures to replace the shift with another employee.

According to the Labor legislation of the Russian Federation, the above list is exhaustive and is not subject to broad interpretation [15].

A distinctive feature of the Labor Code of the Russian Federation is that overtime work is paid for the first two hours of work - not less than one and a half, and for the next hours - not less than double.

Also, overtime work on an individual contract basis, at the request of the employee, can be compensated by providing him with additional rest time (time off), but not less than the time worked overtime. 
In the United States, overtime work is regulated by the Fair Working Conditions Act, according to this Act, overtime is any work performed over 40 hours during a work week and will lie payment not less than one and a half amount. The law also does not stipulate the maximum limits for these works.

A feature of the legal regulation of overtime work in the United States is that states have rather broad powers in the field of labor relations regulation and have the right to pass their own laws, which often worsen the legal status of workers in comparison with the current federal legislation [16].

Some states do not include overtime work performed outside the 40-hour workweek. In Minnesota, overtime is defined as work done outside of 48 hours a week. Kansas law only defines overtime work that is done outside of 46 hours per week. In fact, the laws of these states have increased the working hours to 46 and 48 hours, respectively [17].

In a situation where both state and federal labor standards apply to a worker, they may choose a higher standard of such work schedule (that is, one that pays more overtime). Here one cannot fail to note some inequality in the position of different categories of workers. While some of them do not have the right to paid overtime at all, others, on the contrary, have this right in excess.

Interestingly, the Act does not require the written consent of an employee to work overtime, which allows a US employer to employ employees outside of normal working hours without their written consent.

Due to the absence of a clause as to which side the initiative of these works may come from, the conclusion suggests itself that overtime work in the United States can be performed both on the initiative of the employee and on the initiative of the employer.

In France, the norms on overtime work are enshrined in the French Labor Code, according to this code, work outside 35 hours a week is considered overtime work [18]. At the same time, the maximum working time per week, taking into account overtime hours, should not exceed 48 hours.

Engaging an employee in overtime work is allowed with the approval of the labor inspectorate or the requirement of the consent (opinion) of the trade union (body of the labor collective).

Overtime pay is increased by $25 \%$ for the first 8 hours per week, and subsequent overtime hours are paid at a 50\% increase. As we can see, according to French law, the calculation of overtime is taken not from the daily, but from the weekly working hours [19].

In France, as well as in the Republic of Uzbekistan, at the request of the employee, overtime work can be compensated by providing him with additional rest time (time off).

The maximum number of hours of overtime per year is determined by a collective agreement or industry agreement, and in the absence of contractual regulation, the French Labor Code stipulates that overtime work should not exceed 220 hours per year. As we can see, the maximum amount of overtime work in France is 100 hours more than that provided for by Art.125 of the Labor Code of the Republic of Uzbekistan.

Comparison of the labor legislation of the Republic of Uzbekistan and the legislation of foreign countries on overtime work allows us to conclude that the legislation of Uzbekistan is more socially oriented, which, in particular, manifests itself in the payment of overtime work, limiting the involvement of certain categories of workers in overtime work, limiting 
the maximum number of hours of overtime work, obligatory consent of the employee to engage him in overtime work.

Working at night has advantages and disadvantages for both the employer and the employee. Positive aspects of night work include: for the employer - more intensive use equipment, the ability to increase production; for employees - a larger salary payments due to the fact that night time is paid at an increased rate compared to work in normal conditions or additional rest time.

Night time is seen as a form of flexibility in regulating working hours allowing more effectively combine the performance of work duties with other aspects of a person's life with study, family responsibilities, raising your cultural outlook, improving your physical development without reducing their own income.

Based on the comparative legal analysis of the current norms, it is concluded that the draft of the new edition of the Labor Code of the Republic of Uzbekistan contains a concretized norm regulating night work and overtime work, in comparison with the current Labor Code.

\section{References}

1. Gasanov M.Yu., Sarimsakova G. K. "Legal regulation of working time and rest time". Textbook. - T.: IPTD LLC "Fuqarolik jamiyati", 2017, P. 117.

2. Tursunov Y. Labor law of the Republic of Uzbekistan. - Т.: ТГЮИ, 2005. - Р. 138.

3. Gasanov M.Yu., Sarimsakova G. K. "Legal regulation of working time and rest time". Textbook. - T.: IPTD LLC "Fuqarolik jamiyati", 2017, - P. 118.

4. Lushnikov A.M., Lushnikova M.V. Labor law course: Textbook: In 2 volumes. V. 2. Collective labor law. Individual labor law. Procedural labor law. - M.: Statut, 2009. - S. 460.

5. Labor Code of the Russian Federation of December 30, 2001 N 197-FZ (as revised on December 16, 2019).

6. Labor law of Russia. 3rd edition. Edited by Doctor of Law A.M. Kurennaya. The team of authors, 2015, as amended. LLC "Prospect", 2015 - P. 361.

7. Code du travail, Dernière modification le 01 janvier 2020 // Legifrance.gouv.fr. (French Labor Code of 04.11.2016) https://www.legifrance.gouv.fr /affichCode.do?cidTexte=LEGITEXT000006072050.

8. Filipova I.A. International and National Labor Law. Tutorial. — Nizhny Novgorod: Nizhny Novgorod State University, 2015. - P. 34.

9. Nordova S.M. Legal regulation of working hours under the legislation of the Russian Federation and individual countries of the European Union (comparative legal analysis). Dissertation for the degree of candidate of legal sciences. Moscow - 2019.S. 125.

10. Labor Code of the Republic of Uzbekistan. (Bulletin of the Oliy Majlis of the Republic of Uzbekistan, 1996, National database of legislation, 11.05.2019, No. 03/19/536/3114, 24.05.2019, No. 03/19/542/317, 04.12.2019., No. 03/19/586/4106).

11. Labor Code of the Republic of Uzbekistan. (Bulletin of the Oliy Majlis of the Republic of Uzbekistan, 1996, National database of legislation, 11.05.2019, No. 03/19/536/3114, 24.05.2019, No. 03/19/542/317, 04.12.2019., No. 03/19/586/4106). 
12. 3. Gasanov M.Yu., Sarimsakova G. K. "Legal regulation of working time and rest time”. Textbook. - T.: IPTD LLC "Fuqarolik jamiyati", 2017, P. 126.

13. Lushnikov A.M., Lushnikova M.V. Labor law course: Textbook: In 2 volumes. V. 2. Collective labor law. Individual labor law. Procedural labor law. - M.: Statut, 2009. - P. 473.

14. Labor law of Russia 3rd edition. Textbook / Ed. A. M. Kurennoy - M.: 000 "Prospect", 2015 - S. 311.

15. Labor law of Russia 3rd edition. Textbook / Ed. A. M. Kurennogo - M.: LLC "Prospect", 2015 - S. 312.

16. Kozlov V.S. Legal regulation of working hours in Russia and foreign countries. Dissertation for the degree of candidate of legal sciences. Moscow - 2007.S. 140.

17. Filipova I.A. International and National Labor Law. Tutorial. - Nizhny Novgorod: Nizhny Novgorod State University, 2015. - P. 34.

18. Code du travail, Dernière modification le 01 janvier 2020 // Legifrance.gouv.fr. (French Labor Code of 04.11.2016) https://www.legifrance.gouv.fr /affichCode.do?cidTexte=LEGITEXT000006072050.

19. Filipova I.A. International and National Labor Law. Tutorial. - Nizhny Novgorod: Nizhny Novgorod State University, 2015. - P. 25. 